\title{
The Wisconsin Hydrocephalus Survey: shunt- dependent hydrocephalus management style among members of the American Society of Pediatric Neurosurgeons
}

Mark Richard Kraemer, Bermans J Iskandar

From Hydrocephalus 2015

Banff, Canada. 18-21 September 2015

\section{Introduction}

This survey sought to evaluate differences in the understanding and management of shunt-dependent hydrocephalus among the senior North American Pediatric Neurosurgery membership.

\section{Methods}

Surveys were sent to all active American Society of Pediatric Neurosurgeons (ASPN) members from September to November 2014. A total of 204 surveys were sent from which 130 responses were recorded, representing $64 \%$ of active ASPN membership. Respondents were asked 13 multiple choice and free response questions focusing on four problems encountered in shunted hydrocephalus management: Shunt malfunction, cerebrospinal fluid (CSF) overdrainage, chronic headaches and slit ventricle syndrome (SVS). Qualtrics ${ }^{\circledR}$ online survey software was used to distribute and collect response data.

\section{Results}

ASPN surgeons prefer three varieties of shunt valves: $41 \%$ differential pressure, $29 \%$ differential with antisiphon device (ASD), and 27\% programmable. Respondents agree shunt obstruction occurs most often at the ventricular catheter due to either in-growth of the choroid plexus (67\%), CSF debris (18\%), ventricular collapse (8\%), or other reasons (9\%). Underlying causes of obstruction were attributed to small ventricular size, catheter position, choroid plexus migration, build-up of

\footnotetext{
* Correspondence: mrkraemer@wisc.edu

Department of Neurological Surgery, University of Wisconsin School of Medicine and Public Health, USA
}

\section{Conclusions}

This survey shows discrepancies in shunt-dependent hydrocephalus understanding and management style among a representative group of experienced North American pediatric neurosurgeons. In particular, there are differing opinions regarding the primary cause of ventricular shunt obstructions and the origins of SVS. However, there appears to be general consensus in approach and management of overdrainage and chronic headaches. These results provide impetus for better studies evaluating the pathophysiology and prevention of shunt obstruction and SVS.

\section{Published: 18 September 2015}

\section{References}

ther Mark, Bragg Taryn, Bermans J: Iskandar. Endoscopic Management Neurological Surgeons: Pediatric Section, Amelia Island, Florida, December 2014. 
2. Kraemer Mark, Sandoval-Garcia Carolina, Bermans J: Iskandar: Endoscopic Aqueductoplasty for Treatment of Obstructive Hydrocephalus., Presented at the Shapiro Research Symposium, Madison WI, November 2013.

doi:10.1186/2045-8118-12-S1-035

Cite this article as: Kraemer and Iskandar: The Wisconsin Hydrocephalus Survey: shunt-dependent hydrocephalus management style among members of the American Society of Pediatric Neurosurgeons. Fluids and Barriers of the CNS 2015 12(Suppl 1):035.

Submit your next manuscript to BioMed Central and take full advantage of:

- Convenient online submission

- Thorough peer review

- No space constraints or color figure charges

- Immediate publication on acceptance

- Inclusion in PubMed, CAS, Scopus and Google Scholar

- Research which is freely available for redistribution

Submit your manuscript at www.biomedcentral.com/submit
C) Biomed Central 